|| ISSN(online): 2589-8698 || ISSN(print): 2589-868X || International Journal of Medical and Biomedical Studies

Available Online at www.ijmbs.info

PubMed (National Library of Medicine ID: 101738825)

Index Copernicus Value 2018: 75.71

\title{
PROFILE OF BREAST CANCER PATIENTS ATTENDING A TERTIARY CARE CENTRE: A CROSS-SECTIONAL STUDY
}

\author{
Ganpat Singh Choudhary ${ }^{1}$, Man Singh Bairwa ${ }^{2}$ \\ ${ }^{1}$ Professor, ${ }^{2}$ Senior Resident Doctor \\ Department Of General Surgery, Dr S N Medical College, Jodhpur, Rajasthan
}

Article Info: Received 04 April 2019; Accepted 24 April. 2019

Cite this article as: Choudhary, G., \& Bairwa, M. (2019). PROFILE OF BREAST CANCER PATIENTS ATTENDING A TERTIARY CARE CENTRE: A CROSS-SECTIONAL STUDY. International Journal of Medical and Biomedical Studies, 3(4).

DOI: https://doi.org/10.32553/ijmbs.v3i4.214

Address for Correspondence: Man Singh Bairwa, Department Of General Surgery, Dr S N Medical College, Jodhpur (Rajasthan)

Conflict of interest: No conflict of interest.

\section{Abstract}

Background: World-wide breast cancer is the most frequent type of cancer among females with increasing incidence.

Methods: This study was retrospective and prospective both. Total 40 Female patients of Breast cancer, from all age group admitted in Department of Surgery, Dr. S.N. Medical College, Jodhpur were included.

Results: Lump was presenting feature in all cases $100 \%$. The next most common presenting feature was pain, which was present in $62.5 \%$ cases. $10 \%, 17.5 \%$ and $2.5 \%$ cases had nipple discharge, nipple retraction and skin ulceration.

Conclusion: The highest incidence of breast carcinoma was in 4th, 5th and 6the decades.Majority of the patients was Hindus and of rural areas and all the patients were married female.

Keywords: Breast Carcinoma, Histopathologically Positive, Metastasis

\section{Introduction:}

World-wide breast cancer is the most frequent type of cancer among females with increasing incidence.

In India, it is the second most prevalent cancer in females after cancer of cervix.

The exact cause of breast cancer is not known but certain epidemiologic factors influence its occurrence and predispose to it.

The various etiological and predisposing factors for breast cancer are Genetic, Dietary, Hormonal, Obesity, Radiation, Environmental etc.
Two of the most important prognostic indicators in breast cancer are tumour size and the axillary lymph node status; the size of tumour directly correlating with the probability of nodal metastasis i.e. patients with large breast masses or higher clinical stage is more likely to have positive nodes. Node positive patient experiences relapses usually in distant organs and tissues mainly in bones, lungs, pleura, liver and soft tissues ${ }^{1}$.

It is sometime seen that the clinically palpable axillary nodes often turn out to be nonmetastatic and clinically non-palpable nodes may be found to be positive for metastasis. 
Evaluation of axillary lymph node status is thus an important prognostic factor depending on pathological staging rather than clinical assessment alone. There is also proved a strong correlationship between the size of tumor and the probability of distant metastasis. ${ }^{2}$

The present study carried out to the prognostic factors in breast cancer.

\section{MATERIAL AND METHODS}

SOURCE OF DATA: female patients of Breast cancer, from all age group admitted in Department of Surgery, Dr. S.N. Medical College, Jodhpur.

SAMPLE SIZE: A total of 40 patients. INCLUSION CRITERIA:

- All age group.

- Female patients.

- Patients with proven malignancy.

\section{EXCLUSION CRITERIA:}

- Male patients with breast carcinoma.

- Patients with breast lumps other than carcinoma, proved by history, examination and histopathology.

STUDY DURATION: January 2016 - December 2016(Retrospective)

January 2017 - October 2017(Prospective)

STUDY DESIGN: Prospective and Retrospective.

\section{OBSERVATIONS AND RESUTLS}

The following observations are based on a study conducted on 40 cases of breast cancer patients admitted in various surgical units of Dr. S.N. Medical College, Jodhpur and attached group of Hospitals to establish correlation between tumor size, axillary lymph nodes and metastasis.

TABLE 1: AGE WISE DISTRIBUTION

\begin{tabular}{|c|c|c|}
\hline $\begin{array}{c}\text { Age } \\
\text { (in years) }\end{array}$ & No. of patients & Percentage \\
\hline $31-40$ & 7 & 17.5 \\
\hline $41-50$ & 11 & 27.5 \\
\hline $51-60$ & 13 & 32.5 \\
\hline $61-70$ & 8 & 20 \\
\hline $71-80$ & 1 & 2.5 \\
\hline
\end{tabular}

In this study, the incidence is higher in $4^{\text {th }}, 5^{\text {th }}$ and $6^{\text {th }}$ decade.

TABLE 2: RELIGION WISE DISTRIBUTION

\begin{tabular}{|c|c|c|}
\hline Religion & No. of patients & Percentage \\
\hline Hindu & 36 & 90 \\
\hline Muslim & 4 & 10 \\
\hline Total & 40 & 100 \\
\hline
\end{tabular}

In the present study $90 \%$ patients were Hindus and remaining were $10 \%$ Muslims.

TABLE 3: DISTRIBUTION OF LOCALITY

\begin{tabular}{|l|l|l|}
\hline Locality & No. of patients & Percentage \\
\hline Rural & 22 & 55 \\
\hline Urban & 18 & 45 \\
\hline Total & 40 & 100 \\
\hline
\end{tabular}

Higher percentage of patients was from urban area in comparison to rural area. 
TABLE 4: PRESENT MENSTRUAL STATUS

\begin{tabular}{|l|l|l|}
\hline Menstrual status & No. of patients & Percentage \\
\hline Pre menopausal & 10 & 25 \\
\hline Post menopausal & 30 & 75 \\
\hline Total & 40 & 100 \\
\hline
\end{tabular}

Percentage of breast cancer is slightly more in postmenopausal women as compared to pre menopausal women.

TABLE 5: DISTRIBUTION OF PARITY

\begin{tabular}{|l|l|l|}
\hline No. of children & No. of patients & Percentage \\
\hline 0 & 1 & 2.5 \\
\hline 1 & 4 & 10 \\
\hline 2 & 8 & 20 \\
\hline 3 & 13 & 32.5 \\
\hline 4 & 7 & 17.5 \\
\hline 5 & 4 & 10 \\
\hline$\geq 6$ & 3 & 7.5 \\
\hline Total & 40 & 100 \\
\hline
\end{tabular}

In the present study majority of the patients had 2 and 3 children's.

TABLE 6: TOTAL DURATION OF SYMPTOMS

\begin{tabular}{|l|l|l|}
\hline $\begin{array}{l}\text { Duration of symptoms } \\
\text { (in months) }\end{array}$ & No. of patients & Percentage \\
\hline $1-3$ & 2 & 5 \\
\hline $4-6$ & 9 & 22.5 \\
\hline $7-9$ & 4 & 10 \\
\hline $10-12$ & 17 & 42.5 \\
\hline $13-15$ & 4 & 10 \\
\hline $16-18$ & 4 & 10 \\
\hline Total & 40 & 100 \\
\hline
\end{tabular}

The majority of patients i.e. $80 \%$ came to attend hospital within 12 months after onset of disease.

TABLE 7: DISTRIBUTION OF SYMPTOMS

\begin{tabular}{|l|l|l|}
\hline Symptoms & No. of patients & Percentage \\
\hline Lump & 40 & 100 \\
\hline Pain & 25 & 62.5 \\
\hline Nipple discharge & 4 & 10 \\
\hline Nipple retraction & 7 & 17.5 \\
\hline Skin ulceration & 1 & 2.5 \\
\hline
\end{tabular}


Lump was presenting feature in all cases $100 \%$. The next most common presenting feature was pain, which was present in $62.5 \%$ cases. $10 \%$, $17.5 \%$ and $2.5 \%$ cases had nipple discharge, nipple retraction and skin ulceration.

\section{DISCUSSION}

The main route of spread of breast cancer is by way of the axilla. The presence or absence of palpable lymph nodes within the axilla represents one of the important criteria for clinical staging.

Two of the most important prognostic determinants of breast cancer are the number of axillary lymph nodes and the size of the breast tumor. Although the histologic grading of malignancy and clinical staging are comparable from prognostic standpoint, a more accurate prediction in this regard may be obtained when both are considered.

A study of the correlation between the size of the tumor, number of positive axillary lymph nodes and metastasis is presented herewith carried out on 40 patients admitted in various surgical units of Dr. S.N. Medical College, Jodhpur from January 2016 to October 2017.

In the present study of the patients were female.

The peak incidence of breast carcinoma in this series were in the 4th, 5th and 6th decades. $17.5 \%$ cases were in the age group of 31-40 years and $32.5 \%$ cases were in the age group of $51-60$ years. $27.5 \%$ were in the age group $41-50$ years i.e. $82.5 \%$ cases were above 40 years of age. It denotes that the maximum incidence of breast cancer is found in perimenopasual period.

In 1982 Boova et al observed the most commonly breast cancer occurs between 50-59 years (67\%) followed by $40-49$ years (53\%). Barbara A. Tereatt (1989) however observed that $50 \%$ of all cases occur in patients over 60 years of age. In 1992 Merson et al noted in their series that breast cancer most commonly occurred in women over 60 years of age (33\%) followed by age group of $51-60$ years (30\%), 41-50 (20\%) and less than 40 years (16\%).
Prevalence of breast cancer in any specific religion has not been observed in any of the Western studies. However, in the present study $90 \%$, cases were Hindu and only $10 \%$ comprised of Muslims. Mehmooda Khan et al (1976) found $81.4 \%$ patients to be Muslims in a study Kashmir and only $18.52 \%$ are Hindus. Thus, our finding can be attributed to the predominance of Hindus in our state. Therefore, it cannot be concluded that religion is an important risk factor of breast cancer.

Most of our patients were from rural area, 55\% which may be attributed to less public awareness and difficult access to hospitals among urban population. On the contrary S. Pal (1980) reported only $44 \%$ incidence in urban population.

In our study, all the patients were married females. Limited number of cases in our study and the preponderance of marriage in Indian culture seem to be the reason of zero incidences of unmarried women in the present study. The maximum incidence of breast cancer $(50 \%)$ was observed in women having 3 or 4 children's. and only $2.5 \%$ were nulliparous. These results are contrary to the fact that spinsters are more prone to breast cancer. Machmohan (1970) Paymaster (1972) and Virginia et al (1982) have found nulliparous women to be more prone to the disease.

Lump is the presenting feature in all cases of breast cancer i.e. $100 \%$ followed by pain in $62.5 \%$, nipple retraction in $17.5 \%$ and discharge in $10 \%$ cases in the present study, In study of Koal (1948) 74\% and Haagensen (1956) 84.5\% patients presented primarily with lump in the breast. $40 \%$ of the cases in this study had painless lumps. In comparison, Clayton (1926) 39\%, Haagensen (1956) 70\% and River (1951) $76 \%$ cases came with painless lumps contrary to these Corry (1952) reported only $47 \%$ cases with painless lump.

\section{CONCLUSION}

The highest incidence of breast carcinoma was in 4th, 5th and 6the decades.Majority of the 
patients was Hindus and of rural areas and all the patients were married female.

\section{REFERENCES}

1. Baker R. Robinson: Preoperative assessment of patients with breast cancer. The surgical clinics of North America 64/6, 1984.

2. Calus EB, Risch N, Thompson WD. Autosomal dominant inheritance of early onset breast cancer: Implications for risk prediction. Cancer. 1994;73:643.

3. Boova RS, Bonanni R, Rosato FE.: Patterns of axillary nodal involvement in breast cancer. Predictability of level one dissection. Ann Surg. 1982 Dec;196(6):642-644.

4. Barbara A T. The Edwin Smith Surgical Papyrus. Chicago: University of Chicago Press; 1930.p. 405.

5. Merson M.et al.: Breast cancer presenting as metastasis without evidence of a primary tumor. Cancer vol. 70(2), July 92.
6. Mechmood Khan: Pathologic profile of invasive breast cancer. Ind.J. Cancer vol.20, 15-22, 1983.

7. S.pal et al.: Patterns of relapses and survival mastectomy: Analysis of 716 consecutive patients. Cancer 1978, 41: 1170-1178.

8. Paymaster J.C.: Epidemiology of breast cancer in India. J. Natl. cancer Inst. 48: 1021: 1972.

9. Virginia et al.: Prognostic significance of morphological parameters and flowcytometeric DNA analysis in carcinoma of the breast, Pathal. Annual. 1990; 25A 1: 171-210.

10. Koal. Occult breast cancer presenting with axillary lymph node metastasis: a follow up study of 48 patients. Hum. Pathol.1990 may 21(5), 518-23.

11. Haagensen C.D. et al: Treatment of early mammary carcinoma. A Cooperative international study. Ann Surg 157: 157-179, Feb. 1963. 